A N N A L E S

UNIVERSITATIS MARIAE CURIE-SKŁODOWSKA

LUBLIN - POLONIA

VOL. XXXIV

SECTIO FF

$2-2016$

\title{
EWA ZWOLAK
}

Uniwersytet Marii Curie-Skłodowskiej

\section{Postapokaliptyczna wizja nuklearnej zagłady w powieści Nevila Shute’a Ostatni brzeg}

Post-apocalyptic vision of nuclear holocaust in Nevil Shute's novel On the beach

Mimo stale rosnącej popularności literatury zaliczanej do science fiction wciąż nie udało się stworzyć powszechnie akceptowalnego aparatu badawczego, który umożliwiałby literaturoznawcom jej sprawne i trafne opisywanie. Trudności w ustaleniu katalogu kategorii pojęciowych przeznaczonych do opisu literatury z kręgu fantastyki naukowej należy przypisać temu, że termin science fiction dość szybko zaczął tracić swoją „,iterackość” na rzecz mediów niedrukowanych, w tym przede wszystkim filmów, komiksów, powieści graficznych, gier i symulacji komputerowych ${ }^{1}$. Konwencjonalność tematyki postapokaliptycznej zarówno w literaturze, jak i w filmie idealnie wpisuje się w owe problemy definicyjne. Powołując się na Dominikę Oramus, można stwierdzić, że gatunek ten w istocie jest „tworem paradoksalnym”", co należy thumaczyć tym, że w procesie zatracania tożsamości przeniknął do kultury popularnej, dzięki której mógł zaistnieć w głównym nurcie literackim - najpopularniejszej współcześnie odmianie powieści, określanej dość enigmatycznie mianem postmodernistycznej.

Lokowanie fantastyki naukowej w obrębie nurtu postmodernistycznego znajduje umotywowanie w eseju Frederica Jamesona pt. Postmodernizm i spoleczeństwo konsumpcyjne, w którym autor wiąże ze sobą ponowoczesność z millenaryzmem i silnym przeczuciem zbliżającego się końca ${ }^{3}$. Taka optyka jest szczegól-

${ }^{1}$ D. Oramus, O pomieszaniu gatunków. Science fiction a postmodernizm, Warszawa 2010, s. 7.

${ }^{2}$ Ibidem, s. 8.

${ }^{3}$ F. Jameson, Postmodernizm i społeczeństwo konsumpcyjne, przeł. P. Czapliński, [w:] Postmodernizm. Antologia przekładów, red. R. Nycz, Kraków 1996. 
nie istotna w kontekście tematu niniejszego artykułu, który koresponduje z tym ujęciem. Ponadto, jak referuje Oramus - „postmodernizm, zdaniem Jamesona jest domeną pastiszu: pseudowydarzenia rozgrywającego się w pseudoprzestrzeni medialnego spektaklu"4. Kulturę postmodernizmu charakteryzuje fragmentaryzm, który sprawia, że właściwy dla tego obszaru sztuki dyskurs cechuje się chaosem, czego egzemplifikacją są choćby kolaże w tekstach literackich. Ową fragmentaryczność potwierdza Ihab Hassan, który w artykule Postmodernizm, wyszczególniając cechy tego zjawiska, pisze o różnych, odmiennych orientacjach cywilizacyjnych, zaprzeczając $w$ ten sposób spójnej wizji świata ${ }^{5}$. Istotna w kontekście poszukiwania styczności między ponowoczesnością a science fiction jest charakterystyka postmodernizmu zaproponowana przez Joana Gordona i Veronicę Hollinger, którzy zjawisko to postrzegają w kategoriach temporalnych. Zdaniem autorki opracowania $O$ pomieszaniu gatunków postmodernistyczna cywilizacja rozpatrywana w kontekście pojęcia czasu ulokowana jest gdzieś pomiędzy tym, co właściwe teraźniejszości, a tym, co należy do przyszłości. Jak pisze Oramus, miejsce, w którym owa cywilizacja się znajduje, „opisać można wyłącznie w kategoriach fantastycznych, gdyż dzięki science fiction udaje się tworzyć znaki, których desygnaty jeszcze nie istnieją"6.

Literatura z kręgu fantastyki naukowej zapewnia dostęp do języka, za pośrednictwem którego mówimy o współczesnej rzeczywistości. Źródeł takiego postrzegania science fiction można szukać w eseju Simulacra and Sience Fiction Jeana Baudrillarda, który wyróżnia trzy rodzaje fantastycznych wizji: utopijną, klasyczną science fiction z drugiej połowy XX wieku oraz science fiction czasów symulakr. Zdaniem Baudrillarda jedynie za pośrednictwem trzeciego wariantu można ująć wszystko, co jest właściwe dla współczesności ${ }^{7}$. Jeśli symulowanie potencjalnego i prawdopodobnego upadku cywilizacji jest cechą najważniejszą post-apo, to dyskusyjna klasyfikacja Baudrillarda może okazać się przydatna.

Spore grono twórców fantastyki posługiwało się utartymi schematami fabularnymi, dlatego też jeszcze do niedawna wyodrębnienie podziałów gatunkowych w obszarze fantastyki okazywało się niemożliwe. Oramus zaznacza: „Mówiono na przykład o typie SF opartej na kopiowaniu europejskich wzorców, która dzieliła się na utwory à la Juliusz Verne (czyli o wynalazkach) i à la Her-

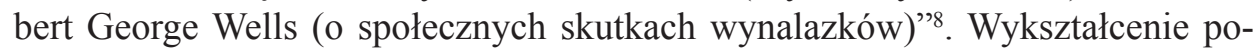
etyki współczesnej fantastyki przypisuje się amerykańskiej kulturze popularnej, w której mniej więcej od połowy lat 50 . XX stulecia zaczęły powstawać spa-

${ }^{4}$ D. Oramus, op. cit., s. 9.

${ }^{5}$ I. Hassan, Postmodernizm, przeł. U. Niklas, [w:] Wspótczesna myśl etyczna. Wybór tekstów, red. R. Różanowski, Wrocław 1993.

${ }^{6}$ D. Oramus, op. cit., s. 11.

${ }^{7}$ J. Baudrillard, Symulakry i symulacja, przeł. S. Królak, Warszawa 2005.

${ }^{8}$ D. Oramus, op. cit. s. 52. 
ce opery i dystopie, na pierwszy plan wysuwające refleksje na temat przyszłości cywilizacji. Ze względu na temat niniejszego artykułu szczególne znaczenie przypisuję fantastyce postapokaliptycznej, która swe istnienie zawdzięcza prozie katastroficznej. Głównym przedmiotem tego podgatunku fantastyki naukowej jest opis końca ludzkiej cywilizacji. Chociaż znane są dziewiętnastowieczne przykłady tego typu literatury, jak np. Ostatni czlowiek Marry Shelley z 1826 roku, to w pełni rozwinęła się ona po wykorzystaniu broni jądrowej w działaniach o charakterze zbrojnym - 6 sierpnia 1945 roku w Hiroszimie oraz 9 sierpnia tego samego roku w Nagasaki. Trwałe skażenie środowiska i choroba popromienna stanowiły asumpt dla świata nauki i mediów do wielu dyskusji, w których próbowano odpowiedzieć na pytanie odnoszące się do tego, czy istnienie cywilizacji po atomowej katastrofie jest w ogóle możliwe. Początkowo dyskurs ten przybierał charakter wyłącznie społeczno-politycznych medytacji teoretycznych, z czasem jednak przerodził się w odmianę literacką beletrystycznych wizji nuklearnej zagłady i jej konsekwencji. Do najpopularniejszych wcieleń motywu opisującego nową, zmutowaną cywilizację, jaka powstała na wskutek skażenia, należy zaliczyć Kantyczkę dla Leibowitza Waltera M. Millera czy Poczwarki Johna Wyndhama. Powieścią, która na trwałe wpisała się w kanon literatury postapokaliptycznej jest również „mainstreamowe” obyczajowe wcielenie motywu nuklearnego holocaustu zaproponowane przez angielskiego pisarza Nevila Shute'a w powieści Ostatni brzeg 9 .

Powieść Shute'a wyrosła nie tylko z narastającej po II wojnie światowej obawy, że broń jądrowa może zniszczyć ludzką cywilizację, ale także ze stanu napięcia towarzyszącego zimnej wojnie. Jak podkreśla Oramus, wówczas ,apokalipsa budziła grozę, ale i fascynację, a zmęczenie współczesnym światem i przeludnieniem w miastach sprawiało, że pomysł zredukowania ludzkości do kilkuset czy kilku tysięcy osobników na całej planecie wydawał się kuszący"10. Ostatni brzeg, można zaryzykować, jest projekcją fascynacji autora futurystyczną przepowiednią, której przedmiotem jest kres ludzkiej cywilizacji. Powieść Shute’a niewątpliwie wpisuje się w nurt postapokaliptyczny, gdyż koncentruje się przede wszystkim na ukazaniu ostatnich dni życia w Australii - państwa, do którego nie dotarł jeszcze śmiercionośny radioaktywny pył. W istocie Ostatni brzeg jest krótkim epilogiem postapokaliptycznym dla samej apokalipsy, bo autor nie pozostawia złudzeń co do tego, że nie ma nadziei na odrodzenie świata ${ }^{11}$. W nowszych realizacjach tego motywu krótkotrwałej postapokalipsy podobnie dzieje się np. w Drodze Cormaca McCarthy'ego. Przyczyną zagłady ziemskiej biosfery jest retrospektywnie przypominana w powieści III wojna światowa [...] której dziejów

${ }^{9}$ R. Latham, Fiction, 1950-1963, [w:] The Routledge Comanion to Science Fiction, LondynNowy Jork 2009, s. 86.

${ }^{10}$ D. Oramus, op. cit., s. 178.

${ }^{11}$ Vide: A. Mousoutzanis, Apocaliyptic SF, [w:] The Routledge Comanion to Science..., s. 460. 
nikt nie spisał i nikt spisać już nie miał, i która natychmiast ogarniając całą półkulę północną, tak samo raptownie się skończyła z ostatnim sejsmicznym wstrząsem po wybuchu wojny w trzydziestym siódmym dniu" (Shute, s. 5). Istotną rolę w powieści, mieszczącej się ideologicznie jeszcze w dojrzałej nowoczesności, pełni refleksja nad politycznymi powodami zagłady (tego już nie ma u McCarthy'ego) ${ }^{12}$. Konflikt zbrojny, stanowiący źródło nuklearnej katastrofy, z której skutkami muszą zmagać się bohaterowie Ostatniego brzegu, w głównej mierze koncentrował się na północy globu, dlatego ostatnią przystanią, gdzie wciąż tli się iskierka ludzkiego istnienia jest południowy brzeg Australii.

W 2016 roku, kiedy przypominamy powieść z połowy XX wieku, przejmująca jest aktualność prekognicji kierunków możliwego rozwoju globalnej sytuacji politycznej. I apokaliptyczne zagrożenie, i polityczni gracze pozostają ci sami, mimo końca bipolarnego świata komunistyczno-kapitalistycznego konfliktu. Także atomowy charakter Zagłady nie byłby nadal niczym zadziwiającym w naszych czasach. Różnica dotyczy jednak napięcia emocjonalnego ówczesnej przepowiedni Shute'a, gdyż dzisiaj podobne lęki uległy w dyskursie publicznym znaczącej erozji. Nie uznajemy ich za realne niebezpieczeństwo najbliższej perspektywy dziejowej. Poczucie historyczności i linearności czasu w nas wygasło. W ponowoczesnym społeczeństwie ryzyka nuklearny konflikt stał się jednym z wielu faktorów możliwości przepowiadania apokaliptycznego końca ${ }^{13}$. Powieść Shute'a jest symptomem lęków ówczesnych, bardzo konkretnych wobec globalnej sytuacji politycznej.

Propozycja futurologiczna Shute'a zaproponowana w Ostatnim brzegu jest kassandrycznym opisem nieodwracalnego wyginięcia gatunku ludzkiego w wyniku następstw wyścigu zbrojeń i zimnej wojny. Mimo że zagłada dotknęła większej części globu, autor, chcąc uwydatnić tragedię postapokaliptycznej wizji wyłaniającej się z podświadomych głębin dwudziestowiecznych antyatomowych lęków, ukazuje istotę tragedii w przejmującej optyce jednostkowej egzystencji ${ }^{14}$. Przyjrzyjmy się tej - typowej dla amerykańskiej prozy - perspektywie różnych punktów widzenia, mozaice spojrzeń z ukosa, z cząstkowych perspektyw zagłady. Wśród głównych bohaterów powieści należy wymienić Petera Holmesa - młodego Australijczyka, świeżo upieczonego męża i ojca, oficera łącznikowego na okręcie podwodnym Stanów Zjednoczonych „Skorpion” oraz Dwighta Towersa -Amerykanina, kapitana Marynarki Wojennej Stanów Zjednoczonych, którego żona Sharon i dwójka dzieci zginęli w wyniku radioaktywnego promieniowania po wybuchu bomby. Mimo to: „Sharon i dzieci to dla niego rzeczywistość, rze-

${ }^{12}$ A. Milner, On the Beach: Apocalyptic Hedonism and the Origins of Postmodernism, [w:] Australian Popular Culture, red. I. Craven, USA 1994, s. 194.

${ }^{13}$ Termin zaproponowany przez Urlicha Becka. U. Beck, Społeczeństwo ryzyka. $W$ drodze do innej nowoczesności, Warszawa 2004, s. 372.

${ }^{14}$ G. Sleight, Breaking the frame, [w:] The Routledge Comanion to Science..., s. 46. 
czywistość znacznie konkretniejsza niż ten problem połowicznego rozpadu substancji promieniotwórczych w dalekim zakątku świata, gdzie los rzucił go po wojnie" (Shute, s. 99). Obaj protagoniści wyznaczają możliwą oś indywidualnego doświadczenia apokalipsy oraz psychologicznych reakcji na Zagładę. Z jednej strony bezradność młodego ojca, który nie jest w stanie zapewnić bezpieczeństwa swemu gniazdu i jedyne, co może ofiarować rodzinie, to godna śmierć bez przedłużonych, absurdalnych cierpień w wyniku popromiennej choroby. Z drugiej strony jest to koszmar umierania w samotności i poszukiwanie związku z kobietą odpowiadającą jego wyobrażeniom partnerki „końca czasów”, fantazji miłości „po grobową deskę". W powieści tą kobietą jest w sugestywny sposób naszkicowana Moira Davidson. To kobieta wyzwolona, lubiąca męskie towarzystwo, otaczająca się wieloma ludźmi, niestroniąca od alkoholu, powszechnie postrzegana jako dusza towarzystwa, a jednak w perspektywie zbliżającego się końca bardzo samotna, potrzebująca ciepła i aprobaty. W galerii znaczących bohaterów należy także wyróżnić John Osborna - fizyka z Organizacji Badań Naukowych i Przemysłowych Wspólnoty Narodów, próbującego odkryć prawdę o przyczynach katastrofy, przed którą stanął cały świat. Ten człowiek jest znaczącym umierającego świata, symbolem Rozumu i Oświecenia, nieudanego projektu nowoczesności.

Dlaczego projekt zakończył się fiaskiem? Historiozofia konfliktu jest wypadkową upadku uniwersalistycznych przekonań modernizmu. Nie ma eschatologicznej logiki apokalipsy wywołanej przez niedoskonałego człowieka. Wspomnienia, których nośnikami są ludzie ocalali z katastrofy, mający jednak świadomość, że ich bytowanie jest w pewnym sensie „tymczasowe”, a koniec bliższy, niż się wielu wydaje, informują o tym, że nieuchronna zagłada to wynik ludzkiej pomyłki. Petera Holmesa powiadamia o tym fizyk, stwierdzając, że bomby atomowej przeciw Rosji użyto właściwie przez przypadek, sugerując się fałszywym przypuszczeniem ataku (Shute, s. 78). To ważny sygnał, pokazujący, że logika „społeczeństwa ryzyka” rodziła się jeszcze w samym centrum nowoczesnego doświadczenia lat 40.-50. XX wieku.

Okres poprzedzający katastrofę został w powieści przedstawiony jako mityczny czas, w którym co rano mleko dostarczane było do domów, benzyny nie brakowało, ludzie wyjeżdżali na zimowe wakacje na narty, mogli realizować swoje pasje, a poziom promieniowania radioaktywnego nigdy nie przekraczał dawek zabójczych dla człowieka. Z kolei postapokaliptyczny obraz wyłaniający się z powieści jawi się jako krótki okres, w którym pewne - dotąd przyjęte i powszechnie aprobowane - wzorce zachowania uległy zatarciu, co stanowiło konsekwencję tego, że w obliczu zagłady, przed którą stanęli główni bohaterowie Ostatniego brzegu, potrzeby najniższego, ale biologicznie prymarnego rzędu wyznaczają bieg ludzkiej egzystencji. Również pojęcie czasu w perspektywie nieuniknionego końca podlega dezaktualizacji, bowiem optyka postapokalipsy spra- 
wia, że ludzki czas - cykliczny, mierzony od początku do końca świata - wypełnił się, historia zatoczyła koło, a dla teraźniejszości właściwy jest czas linearny, który dobiega końca ${ }^{15}$.

Obraz końca świata wyłaniający się z powieści Shute'a nie ma za wiele wspólnego z apokaliptyczną wizją św. Jana, bowiem miasta nie są doszczętnie zniszczone, a śmierć przychodzi znienacka, po cichu i nikt nie zna jej prawdziwego oblicza, jak powiada jeden z bohaterów Ostatniego brzegu - John Osborne: „w istocie nie wiemy, co tam się dzieje... na samym końcu” (Shute, s. 231). Odpowiedzi na pytanie, jaki koniec ich czeka, a zarazem śladów życia, czyli nadziei na ocalenie, poszukują członkowie załogi „Skorpiona” pod wodzą kapitana Towersa. Dokonując inspekcji San Francisco, stwierdzają, że:

[...] jedynie most się zawalił. Wieża podtrzymująca go od strony południa najwyraźniej runęła. Widoczne z morza gmachy przy Parku Złotych Wrót mocno ucierpiały od ognia i podmuchów; żaden z nich chyba nie nadawał się już do zamieszkania. Oznak życia ludzkiego nigdzie nie wypatrzyli, sam zresztą wysoki stopień radioaktywności wykluczał przypuszczenie, żeby ktokolwiek mógł jeszcze żyć na tym obszarze (Shute, s. 164).

Chociaż perspektywa końca, który „następuje w dość szybkim tempie” (Shute, s. 231), jest nieuchronna, ludzie prowadzący egzystencję na australijskim tytułowym „ostatnim brzegu” potrafią przekuć towarzyszący im lęk w życie chwilą szczęścia. Dobrym przykładem bohatera, pragnącego wykorzystać czas, jaki mu pozostał, jest John Osborne. Fizyk spełnia jedno ze swoich największych marzeń: bierze udział w wyścigach samochodowych, na które zawsze brakowało mu pieniędzy. Cena czasu jest tutaj pewną egzystencjalną wygraną. Czasy hedonistycznego powodzenia i bezpieczeństwa rozleniwiały. Acedia prowadziła ku życiu pozbawionemu znaczącej treści. Czas post-apo jest zatem nie tylko czasem zagłady, ale też quasi-mesjańskim przebudzeniem, zawieszeniem rutyny przed ostatecznym wyrokiem. A więc być może jedynym realnym w sensie pełnowartościowości momentem istnienia.

Na kartach Ostatniego brzegu śmierć gatunku została ukazana jako siła demokratyzująca ludzkość. Zbiera największy w swojej historii plon, który nie dzieli. Jak powiada jeden z bohaterów: „Wszyscy jedziemy na tym samym wózku” (Shute, s. 13). Echo podobnych słów, zarazem apokaliptycznych, jak i empatycznie solidarystycznych, przewija się przez całą powieść. Przed obliczem końca, mającego nastąpić w wyniku radioaktywnego promieniowania w dawce zabójczej dla istot żywych, staniemy wszyscy bez względu na wiek, reprezentowany status społeczny, poglądy czy wyznawaną religię - nawet mała Jennifer, córka Mary i Petera, nie jest w żaden sposób uprzywilejowana. Efekt ten dodatkowo wzmacnia fakt, że zwierzęta przeżyją ludzi i to dzięki nim będzie się tliła ostatnia iskierka życia na świecie:

${ }^{15}$ D. Oramus, op. cit., s. 183. 


\begin{abstract}
- Chcesz przez to powiedzieć, że króliki będą żyły dłużej niż my, ludzie?
- Otóż to. Mniej więcej o rok dłużej. Mają prawie dwa razy większą odporność niż my. Więc w przyszłym roku po Australii będą biegać króliki, wyjadając naszą żywność.

- Powiadamiasz, że jakieś cholerne króliki nas ostatecznie przetrzymają? Będą żyć i brykać, kiedy my dawno już pomrzemy?

John Osborne przytaknął.

- I psy nas przeżyją. Myszy przetrwają znacznie dłużej, ale przecież nie aż tak długo, jak króliki. O ile możemy przewidzieć, królik pobije wszystkich... królik będzie ostatni. - Urwał. (s. 237)
\end{abstract}

Ostatni królik to oczywiście ironiczny efekt apokalipsy wywołanej przez człowieka. W kontekście Ostatniego człowieka Shelley nawet to prawo zostało nam odebrane: nie jesteśmy beneficjentami festynu Zagłady. Nie konsumujemy jej do końca, nie upajamy się naszym umieraniem, nie możemy aspirować do miana ostatnich istot na Ziemi. A przecież takie atrakcje przepowiadały nam po ludzku narcystycznie antropocentryczne biblijne objawienia.

Równie słynna jak powieść Shute'a jest jej ekranizacja, która stanowi swoisty komentarz do powieści - bardzo współczesny, aktualny. Postapokaliptyczna wizja nuklearnej zagłady ludzkości, jaką przynosi lektura powieści, stanowi zbeletryzowany głos autora na temat niebezpieczeństwa wypływającego z możliwości ponownego użycia broni jądrowej. To właśnie popularność i powszechność lęku, w jaki wpisywał się Ostatni brzeg, zaowocowała szybkim stworzeniem adaptacji w 1959 roku. Akcja filmowej wersji Ostatniego brzegu w reżyserii Stanleya Kramera rozgrywa się kilkanaście miesięcy po wojnie nuklearnej ${ }^{16}$. Jak sugeruje jedna z początkowych scen ekranizacji, mamy rok 1964. Ostatnie życie tli się jeszcze na wybrzeżu w południowej Australii, do którego przybywa zaledwie kilka ocalałych z katastrofy jednostek floty amerykańskiej, czyniąc sobie z ostatniej, chociaż tymczasowej ostoi bezpieczeństwa, schronienie.

Ekranizacja, podobnie jak i sama powieść, przynosi sugestywny obraz następstw atomowej katastrofy, w wyniku której ludzie umierają w milczeniu bez krzyków, płaczu, oskarżeń i bezsensownej walki o dalszy byt ${ }^{17}$. Film jednak nie stanowi wiernego odtworzenia sensów wypływających z lektury powieści Shute'a, co szczególnie ujawnia się w zakończeniu. W ostatnich partiach książki uwaga autora została skupiona przede wszystkim na Moirze, której śmierć przynosi na poły romantyczny obraz, wpisujący się w motyw miłości mającej szansę na realizację dopiero po przekroczeniu bramy innego świata. Z kolei zakończenie ekranizacji stanowi jednoznaczną aluzję historiozoficzną, ilustrację możliwości użycia bomby atomowej w niedalekiej przyszłości. Jest realnym ostrzeżeniem przed nieuniknionymi konsekwencjami takiej decyzji. Samobójcza śmierć Moiry i młodego małżeństwa Homlesów to część emocjonalnej gry, jaką prowadzi

${ }^{16}$ Ostatni brzeg [film], reż. S. Kramer, USA 1959.

${ }^{17}$ P. Wright, Film and Television 1960-1980, [w:] The Routledge Comanion to Science..., s. 91. 
z czytelnikami autor powieści, natomiast analogiczny fragment filmu stawia wszystkich oglądających przed mocą unaocznienia filmowego obrazu. Informuje dobitnie o realnej groźbie wypełnienia się takiego scenariusza. Wszak identyfikacja z postacią filmową jest zasadą działania filmowego wehikułu. Efekt prawdopodobieństwa został jeszcze po premierze obrazu spotęgowany przez realia zimnej wojny, której kubańskie kulisy rozgrywały się niedługo po wejściu adaptacji na ekrany kin.

Stanley Kramer - reżyser adaptacji Ostatniego brzegu - zdecydował się również na odrzucenie wątków, w których uobecniają się konflikty o charakterze politycznym, będące powieściową próbą wyjaśnienia tego, kto stoi za wykorzystaniem broni jądrowej do działań zbrojnych. Film przede wszystkim oddaje kwintesencję oswojenia się z nieuchronną perspektywą śmierci w wyniku choroby popromiennej, której objawy w tajemniczy, niemal niewidzialny sposób zabiją wszystkich mieszkańców ostatniego australijskiego miasta - Melbourne. W koniec ludzkości w tym krótkim czasie post-apo wpisany jest rytm życia rodzinnego, miłości kochanków i rodziców, życie bliskie naturze, uprawianie ogrodu, fiesty po zwykłej fizycznej pracy, arkadyjskiego, niemal utopijnego obrazu cywilizacji, którą wyłącznie z własnej winy tracimy.

Odnosząc się zarówno do powieści, jak i jej dość wiernej adaptacji, zauważmy i podkreślmy ich cechy wspólne. Porażająca futurologiczna wizja III wojny światowej zdumiewa swoją absurdalnością. Trwająca zaledwie 37 dni zagłada, po której odczyty sejsmiczne określały liczbę zrzuconych bomb na 4700, stała się kresem dla niemal całego świata. Życie toczy się jednak swoim codziennym rytmem i chociaż ludzie zdają sobie sprawę, że w ich egzystencję wpisany jest nieunikniony i coraz bliższy koniec, starają się stale przesuwać granice nadchodzącej śmierci i tworzyć pewien pozór normalności. Patrząc na książkę i jej ekranizację, można uznać, że jest to życie niemal mesjańskie, w „czasie który pozostał" - stosując pojęcie Agambena, analizującego (ujmijmy to żartobliwie) znaną narrację post-apo św. Pawła w jego liście do Rzymian. Życie jest intensywniejsze, bardziej uważne, trzeźwe w sensie powagi każdego gestu. Wszystko tutaj staje się pożegnaniem, ale zarazem sygnaturą człowieczeństwa w tym, co w ludzkości było najlepsze. Australijczycy u kresu dni swoją postawą niejako negują ideę zbliżającego się kresu znaczenia ich życia. Zapobiegliwość i „krzątactwo” (tak ujęłaby te ludzkie cechy profesor Jolanta Brach-Czaina $)^{18}$ widać dosłowniej - bo naocznie - w filmie. Przykładowo Mery Holmes, żona Petera, wykazuje wręcz obsesyjną dbałość o swój ogródek: planuje kupno nowej, niewielkiej kosiarki, wstawienie do ogrodu ławki, aby wraz z mężem mogli napawać się urokami naturalnego otoczenia letnią porą, której przecież oboje mieli pewność już nie dożyć.

${ }^{18}$ J. Brach-Czajna, Szczeliny istnienia, Warszawa 1999. 
Wszystko to prowadzi do istoty ludzkiej pracy, jej etosu - etycznego i estetycznego, bo ofiarowującego żywym istotom sens istnienia. I tak w powieści utrzymywaniu czystości w owym dającym państwu Holmes rozległy widok na zatokę ogrodzie towarzyszyło irracjonalne poczucie bezpieczeństwa. Tuż po rozmowie z mężem, że zostały im już tylko dwa tygodnie życia, Mery martwi się o trawnik w ogrodzie, odrzucając od siebie myśl o śmierci:

\footnotetext{
- Ile jeszcze czasu Peter?

- Około dwóch tygodni - odpowiedział. - To się nie dzieje błyskawicznie: pstryk! i po wszystkim. Ludzie zaczynają chorować, ale nie jednocześnie rzecz jasna.

$[\ldots]$

Spojrzenie jego padło na kosiarkę. - Możemy wyrównać trawnik dziś po południu.

- Trawa jest zupełnie mokra - powiedziała markotnie. Ona zardzewieje (Shute, s. 243-244).
}

Czas mesjański to w istocie czas zawieszony, odroczony. Nie ma horroru linearnej logiki zagłady. Jest ogród z jego aksjologią czasu natury, wiecznego powrotu w kole życia. Dowodem na wypieranie ze świadomości zbliżającej się zagłady w przypadku Mery, była zapobiegliwa i utrwalająca ład istnienia dbałość o ogród. Z kolei Dwight Towers nie może przyjąć bolesnej dla niego prawdy o śmierci najbliższych, wydaje mu się, że został wysłany na misję do Australii, a jego rodzina prowadzi spokojną i niczym niezakłóconą egzystencję w Stanach Zjednoczonych. Dlatego też podczas pobytu w Australii kupuje zmarłej już żonie prezent:

\footnotetext{
Bransoleta jaśniała na czarnym aksamicie. Z kolei Dwight ją wziął, żeby obejrzeć. Subiekt nie przesadził, mówiąc, że jest bardzo piękna. Takiej biżuterii Sharon jeszcze w swojej szkatułce nie ma. Na pewno będzie zachwycona.

$[\ldots]$

Dwight wyobrażał sobie radość Sharon. - Wezmę ją. - zadecydował (Shute, s. 159).
}

Problematykę automistyfikacji, zafałszowania przed sobą rzeczywistości dla „sprawy”, dla ocalenia podwalin sensu istnienia można również rozważać w kontekście Moiry Davinson, która chcąc uszczęśliwić kapitana Towersa - miłośnika wędkowania - postarała się o przyśpieszenie sezonu wędkarskiego, który w terminie już nigdy miał nie nadejść. Można powiedzieć, że we wszystkich tych gestach ich trwałą cechą jest wierność międzyludzkim rytom. Byłaby to więc odmiana świeckiej etyki Josepha Conrada w kontekście apokaliptycznego końca, ich conradowska „wierność w klęsce”. Co ciekawe, podobne intuicje - ocalania minimum egzystencjalnej moralności ludzkich działań - towarzyszą też wymienianej już postmodernistycznej post-apo Drodze Cormaca McCarthy'ego.

Ostatni brzeg stanowi mistrzowską prefigurację futurologicznej wizji zagłady ludzkości, ukazanej na przykładzie zwykłych, przeciętnych ludzi, których kre- 
acja niewiele ma wspólnego z pełnym patosu archetypem postawy poświęcenia się dla dobra ludzkości. Shute nie daje bohaterom nadziei, bowiem jak powiada jeden z nich:

[...] wszystko już zaczyna przechodzić pyłem radioaktywnym. Powietrze, którym oddychamy, woda, którą pijemy, sałata, którą jemy, nawet boczek i jajka. To już tylko zależy od wytrzymałości organizmu. Wcale nie jest wykluczone, że u niektórych mniej odpornych objawy mogą wystąpić już za dwa tygodnie. Albo i wcześniej (Shute, s. 229).

Jedynym wybawieniem od spotkania się oko w oko z nieznanym obliczem śmierci w wyniku radioaktywnego promieniowania ma być tabletka trucizny źródło ukojenia, rozdawane wszystkim chętnym. Lek umożliwiający przedwczesny zgon stanowi jedno z wyjść z sytuacji beznadziejnej (Shute, s. 143). Peter jako człowiek o zdroworozsądkowym oglądzie rzeczywistości zdaje sobie sprawę z tego, że chcąc uchronić córkę od fizycznego cierpienia, będącego nieodłączną konsekwencją choroby popromiennej, jest zmuszony poświęcić spokój sumienia i podać jej śmiercionośny lek, a następnie zażyć go samemu wraz z żoną.

Optyka, w jakiej została ukazana zagłada ludzkości, prowadzi do pytania o przyczyny wojny, w której użyto śmiercionośnej broni. Film i książka są tutaj wierne historiozofii autora. Pisaliśmy już we wstępie, że interesują go racjonalne przyczyny dziejowe, polityczne i społeczne. Film unika jednoznacznych oskarżeń, ale widz ma świadomość winy wspólnoty, całego ludzkiego polis. Shute, obnażając absurd wpisany w wojnę, bez cienia wątpliwości wskazuje na niezrozumiałe decyzje polityczne oraz przerost ambicji elit rządzących. Według niego bohaterowie powieści skazani są bowiem na zagładę w wyniku błędu popełnionego przez innych przedstawicieli swojego gatunku. Jednak mimo to wielu z nich nie jest w stanie pojąć, dlaczego muszą ponosić najgorszą z możliwych kar za błędy innych:

- Ja się nie pogodzę - wybuchnęła Moira. - To niesprawiedliwe. Nikt na półkuli południowej nigdy nie rzucił bomby ani wodorowej, ani kobaltowej, ani w ogóle żadnej innej. Nie mieliśmy z tym nic wspólnego. Czy mamy zginąć tylko dlatego, że jakimś państwom oddalonym o dziewięć czy dziesięć tysięcy mil zachciało się wojny? Cholerna niesprawiedliwość (Shute, s. 38).

Nikt nie może się pogodzić - ale każdy staje w prawdzie z jednej strony koniecznej konsekwencji ludzkiego zła, z drugiej świadomości piękna i wartości istnienia. Żyją jeszcze przez chwilę na australijskiej plaży, by dać świadectwo zarówno wagi istnienia, jak i zagłady. Ale płacą za swe życie. Zbiorowa odpowiedzialność jest tutaj nawiązaniem do okrutnej logiki Janowego Objawienia. Nie istnieje zwolnienie od odpowiedzialności za grzech pierworodny całej ludzkości. Nie sposób zrozumieć motyw postępowania osób, które doprowadziły do tej tragedii, jednak - jak powiada jeden z bohaterów Ostatniego brzegu - „Może byliśmy zbyt niemądrzy, żeby na taki świat zasłużyć” (Shute, s. 81). 


\section{BIBLIOGRAFIA}

Agamben G., Czas, który zostaje. Komentarz listu do Rzymian, przeł. S. Królak, Warszawa 2009.

Baudrillard J., Symulakry i symulacja, przeł. S. Królak, Warszawa 2005.

Brach-Czajna J., Szczeliny istnienia, Warszawa 1999.

Hassan I., Postmodernizm, przeł. U. Niklas, [w:] Współczesna myśl etyczna. Wybór tekstów, red. R. Różanowski, Wrocław 1993.

Jameson F., Postmodernizm i społeczeństwo konsumpcyjne, przeł. P. Czapliński, [w:] Postmodernizm. Antologia przekładów, red. R. Nycz, Kraków 1996.

Latham R., Fiction, 1950-1963, [w:] The Routledge Comanion to Science Fiction, Londyn-Nowy Jork 2009.

Milner A., On the Beach: Apocalyptic Hedonism and the Origins of Postmodernism, [w:] Australian Popular Culture, red. I. Craven, USA 1994.

Mousoutzanis A., Apocaliyptic SF, [w:] The Routledge Comanion to Science Fiction, LondynNowy Jork, 2009.

Ostatni brzeg [film], reż. S. Kramer, USA 1959.

Sleight G., Breaking the frame, [w:] The Routledge Comanion to Science Fiction, Londyn-Nowy Jork 2009.

Shute N., Ostatni brzeg, przeł. Z. Kierszys, Warszawa 1979.

Wright P., Film and Television 1960-1980, [w:] The Routledge Comanion to Science Fiction, Londyn-Nowy Jork 2009.

\section{STRESZCZENIE}

Artykuł dotyczy postapokaliptycznej wizji końca świata, jaka wyłania się z powieści Nevila Shute'a Ostatni brzeg, która została zestawiona z jej ekranizacją z 1959 roku w reżyserii Stanleya Kramera. Głównym celem przyświecającym artykułowi było oddanie rangi ważności ponadczasowego dzieła, wpisującego się w nurt postapokaliptyczny. Owa futurologiczna propozycja stanowi kasandryczny opis wyginięcia gatunku ludzkiego, które następuje w wyniku nieprzemyślanych i lekkomyślnych decyzji wykorzystania broni jądrowej. Autor powieści ukazuje zagładę ludzkości w perspektywie jednostkowej egzystencji, czyniąc koniec świata doświadczeniem osobistym. Shute w Ostatnim brzegu często podkreśla, że katastrofa, jaka spadła na ludzi, w których wciąż tli się iskierka nadziei na ocalenie, jest wynikiem pomyłki niedoskonałego człowieka, który zatracił się w wierze w oświeceniowe ideały wszechmocy rozumu ludzkiego. Istotne jest, że Shute'owska wizja nuklearnej zagłady świata stanowi niewyczerpane źródło inspiracji dla współczesnych zakresie motywu zagłady, gdyż jest ona nowoczesnym obrazem końca, wypływającym z głębi XX wieku.

Słowa klucze: post-apo, postapokalipsa, koniec świata, nuklearna zagłada, zimna wojna, era atomowa, kryzys rozumu

\section{SUMMARY}

The article concerns the post-apocalyptic vision of the end of the world, which emerges from the novel by Nevil Shute - On the Beach, which was juxtaposed with its screen version from 1959, directed by Stanley Kramer. The main goal of the article was to demonstrate the validity of timeless masterpiece, which constitutes a part of post-apocalyptic trend. On the Beach is a fatalistic story of extinction of the human species which occurs as a result of a hasty and reckless decision to use 
nuclear weapons. The author of the novel reveals the annihilation of humanity in the perspective of individual existence, making the end of the world a personal experience. Shute frequently emphasizes that the disaster, which happened to people among whom there is still a glimmer of hope for survival, is the result of mistakes of an imperfect man who believed too much in the omnipotence of the human mind. It is important that Shute's vision of nuclear holocaust of the world is an inexhaustible source of inspiration for the modern realization in terms of destruction motifs, because it is a modern image of the end, which stems from the depths of the twentieth century.

Keywords: post-apo, post-apocalyptic, end of the world, nuclear holocaust, the Cold War, atomic age, the crisis of the mind 